\title{
A TINY SPIDER
}

A tiny spider rides on a wisp of gossamer into the setting sun

A fragile entity in the universe, trusting its destiny to the wind.

Knowing no tomorrow, nor yesterday, only the reality of each day it is granted life

- Bernard de Vries, 2000

\section{INSECT TRAP}

Not a loud mouth

like the raucous Magpie and Raven

screeching to announce their presence.

But a quiet mouth

filled with liquid notes,

soft trills and twitters

bubbling rapidly, continuously.

Not a small mouth

like the Hummingbird with long, slender bill reaching into bell flowers for nectar.

But a wide mouth

to trap flying insects, short beak with bristles for funnelling aerial plankton into the gaping maw.

Chattering insectivore pro, Trapper Barn Swallow.

- Jean MacKenzie, An Exaltation of Birds, 1999 


\section{OVENBIRD}

Tired of housekeeping chores

tending an oven (almost built)

she-smartly arrayed in

russet headdress

olive-brown coat, open

revealing a clean

black-striped white dress-

leaves her forest-floor home

and steps with showy pink legs

to the roadway

This grass-edged trail's her promenade

to be walked with much to-do

half-whirls and stops

and bobs (of tail)

and dabs (with beak)

her mincing gait

that of an old, old song's

old lady's passing by

some business here

and business there

an avian outdoor kind of

window shopping

Then satisfied, refreshed

she seeks once more

her oven-nest embedded in dry leaves

arched-over, hidden, and secure

- Victor C. Friesen 


\section{THE JOY OF RAIN}

A quiet mist of rain descends

graying the fragrant air

blacking furrowed trunks of trees

beading the pendant foliage

Each dripping tree-umbrella is

a sheltering green cave

cool, moist, and lattice-windowed

a saunterer's brief snug haven.

- Victor C. Friesen

\section{A SIMPLE THING}

In mid-March I happened to see

a red squirrel atop a snowbank just as l've often seen before but this one surprised me by simply stopping, lowering its head and then eating snow... of course, I reasoned, that's how they get water in winter...but it was a neat thing to see.

- Bob Nero

\section{"YELLOW HAMMER"}

There are laws for the human about noise pollution but this shrill bird has never heard of such edicts for he projects 
loudly

and repeatedly,

"Flick! Flick! Flick!

or "Wick! Wick! Wick!"

as variation

in pronunciation.

During courtship time, considering himself handsome and glamourous, he becomes more clamourous, shouting, "Kee-oo! Kee-oo!" and beating a loud tattoo, as amourous proof, on a wooden house roof, or even on a metal pole. Has he no emotional control? Must he so reverberate his grand passion for his mate?

Such a crazy lover

and intemperate drummer should be confined incarcerated summarily temporarily for sentimental inebriation and lovesick intoxication. Charge him for shredding the quiet of early morning. Raucous sleep-wreckerYellow-shafted Flicker.

- Jean MacKenzie, An Exaltation of Birds, 1999 